\title{
DETERMINAN KINERJA KARYAWAN PADA DINAS PEMBERDAYAAN MASYARAKAT DAN DESA KABUPATEN NGANJUK
}

\author{
Deni Wahyu Eka Wijaya ${ }^{1)}$; Diah Ayu Septi Faujin) \\ 1) deniwahyuekawijaya@gmail.com, Universitas Nusantara PGRI Kediri* \\ ${ }^{n)}$ septifauji@unpkediri.ac.id, Universitas Nusantara PGRI Kediri \\ *email korespondensi
}

\begin{abstract}
This study aims to determine the effect of work discipline, work environment and competence on the performance of employees of the Community and Village Empowerment Service of Nganjuk Regency. In this study using quantitative research methods with data collection techniques through interviews, observation and questionnaires. Sampling in this study used a non-probability sampling technique. The population in this study were employees of the Community and Village Empowerment Service of Nganjuk Regency, amounting to 42 people. The analytical tools used in this research are validity test, reliability test, classical assumption test, multiple linear regression test, $t$-test and F-test. The results showed that work discipline and competence had a positive but not partially significant effect on employee performance, the work environment had a positive and partially significant effect on employee performance and work discipline, work environment, competence had a positive and significant effect simultaneously on employee performance.
\end{abstract}

Keywords : Performance, work discipline, work environment, competence.

\begin{abstract}
Abstrak
Penelitian ini bertujuan untuk mengetahui pengaruh disiplin kerja, lingkungan kerja dan kompetensi terhadap kinerja karyawan Dinas Pemberdayaan Masyarakat dan Desa Kabupaten Nganjuk. Dalam penelitian ini menggunakan metode penelitian kuantitatif dengan teknik pengumpulan data melalui wawancara, observasi dan penyebaran kuesioner. Pengambilan sampel dalam penelitian ini menggunakan teknik nonprobability sampling. Populasi dalam penelitian ini adalah pegawai Dinas Pemberdayaan Masyarakay dan Desa Kabupaten Nganjuk yang berjumlah 42 orang. Alat analisis yang digunakan dalam penelitian ini yaitu uji validitas, uji reliabilitas, uji asumsi klasik, uji regresi linier berganda, uji-t dan uji-F. Hasil penelitian menunjukkan bahwa disiplin kerja dan kompetensi berpengaruh positif namun tidak signifikan secara parsial terhadap kinerja karyawan, lingkungan kerja berpengaruh positif dan signifikan secara parsial terhadap kinerja karyawan dan disiplin kerja, lingkungan kerja, kompetensi berpengaruh positif dan signifikan secara simultan terhadap kinerja karyawan.
\end{abstract}

Kata Kunci : Kinerja, Disiplin kerja, Lingkungan kerja, Kompetensi.

\section{PENDAHULUAN}

Kinerja menjadi masalah utama dalam sebuah organisasi atau lembaga instansi. Kinerja yang memuaskan dari karyawan tidak begitu saja terjadi dengan sendirinya melainkan melalui sebuah proses dan dibutuhkan evaluasi secara berkelanjutan. Menurut Kasmir (2019:184) kinerja ialah hasil kerja dan perilaku kerja yang telah dicapai dalam pemenuhan tugas dan tanggung jawab yang diberikan selama periode waktu tertentu.

Keberhasilan upaya peningkatan kinerja karyawan mempunyai keterkaitan langsung dengan manajemen sumber daya manusia yang efektif di tingkat individual, tingkat organisasi dan kelompok kerja. Sumber daya menusia sangat menentukan manajemen yang ada dalam organisasi, artinya kinerja yang sesuai harapan akan terwujud bila manusia mempunyai daya dan kemampuan yang sesuai dengan tuntutan kebutuhan dalam melaksanakan kegiatan organisasi.

Organisasi membutuhkan karyawan yang mampu bekerja lebih baik, cepat dan tepat. sehingga diperlukan karyawan yang mempunyai kinerja (job performance) yang tinggi. Faktorfaktor yang mempengaruhi kinerja pegawai menurut Kasmir (2019:189) yaitu: keterampilan dan pengetahuan khusus, pengetahuan, desain pekerjaan, kepribadian, motivasi kerja, kepemimpinan, gaya manajemen, budaya organisasi, kepuasan kerja, iklim kerja, loyalitas, komitmen. dan disiplin pekerjaan. 
Dalam sebuah organisasi, karyawan mempunyai kinerja yang berbeda-beda. Kinerja karyawan dipengaruhi oleh beberapa faktor. Menurut Afandi (2021:86-87) ada beberapa faktor-faktor yang mempengaruhi kinerja yaitu kemampuan, kepribadian dan minat kerja, kejelasan dan penerimaan seseorang pekerja, tingkat motivasi pekerja, kompetensi, fasilitas kerja, budaya kerja, kepemimpinan, disiplin kerja.

Sedangkan menurut Kasmir (2019:189-93) ada beberapa faktor yang mempengaruhi kinerja yaitu kemampuan dan keahlian, pengetahuan, rancangan kerja, kepribadian, motivasi kerja, kepemimpinan, gaya kepemimpinan, budaya organisasi, kepuasan kerja, lingkungan kerja, loyalitas, komitmen dan disiplin kerja. Di dalam suatu organisasi diperlukan yaitu disiplin kerja, pengetahuan, lingkungan kerja. Disiplin yaitu mematuhi hukum dan peraturan yang berlaku. Disiplin anggota kerja dapat diartikan kegiatan anggota yang bersangkutan sesuai perjanjian kerja dengan organisasi dimana dia bekerja. Pengetahuan yaitu kreatifitas dalam membentuk ide dalam merencanakan sesuatu yang berkaitan dengan tujuan organisasi. Lingkungan kerja yang baik dan mendukung juga dibutuhkan dalam suatu organisasi/instansi. Pegawai yang peduli terhadap lingkungan kerja baik untuk kenyamanan pribadi maupun untuk menyelesaikan tugas dengan nyaman dan sesuai target.

Dari sekian banyak variabel yang telah dijabarkan, dalam penelitian ini mengambil sebayak tiga variabel yaitu disiplin kerja, lingkungan kerja dan kompetensi. Penelitian ini mengambil objek pada Dinas Pemberdayaan Masyarakat dan Desa Kabupaten Nganjuk yang mempunyai tugas melaksanakan urusan Pemerintahan Daerah di Bidang Pemberdayaan Masyarakat dan Desa, karena dalam instansi tersebut terdapat berbagai fenomena yang layak untuk dijadikan bahan penelitian. Untuk itu kantor Dinas PMD memerlukan kinerja pegawai yang tinggi untuk mencapai tujuan atau target organisasi. Kantor Dinas PMD memerlukan disiplin kerja yang tinggi guna meningkatkan produktivitas \& ketaatan terhadap aturan yang berlaku pada Dinas PMD Kabupaten Nganjuk.

Disiplin merupakan titik awal dari setiap keberhasilan dalam memenuhi tujuan suatu organisasi, penegakan disiplin dalam suatu organisasi adalah untuk memastikan bahwa semua karyawan organisasi secara sukarela dan tanpa paksaan untuk mematuhi dan mematuhi aturan dan peraturan tersebut. Disiplin karyawan yang baik dibuktikan dengan tingginya tingkat kesadaran karyawan dalam mematuhi segala peraturan dan perundang-undangan yang berlaku. Tanggung jawab atas penyelesaian setiap tugas, kesediaan karyawan untuk mematuhi norma dan budaya yang berlaku dalam organisasi, dan untuk meningkatkan efektivitas dan efektivitasnya. Berdasarkan hasil wawancara dengan Bapak Didik Eka Wahjudi selaku Kasubag umum di Dinas Pemberdayaan Masyarakat dan Desa yaitu tentang kedisiplinan pegawai DPMD, pegawai masih banyak yang belum mematuhi peraturan pada DPMD, seperti pada saat jam kerja ada pegawai yang keluar kantor tanpa ada kepentingan yang bersifat resmi dan juga pegawai tidak menggunakan seragam dinas sesuai aturan organisasi.

Terkait dengan lingkungan kerja peneliti mendapatkan informasi dengan melakukan wawancara kepada Bapak Ary Indra Djatmika selaku staff bidang pemerintahan dan kerja sama DPMD "Lembaga instansi sudah memberikan fasilitas kerja yang memadai, namun ada yang perlu ditambah dan dibenahi, Sebagian pegawai mengeluhkan beberapa fasilitas yang kurang baik, perlunya upgrade komputer yang masih menggunakan komputer generasi lama, terbatasnya jumlah printer sehingga terkadang pegawai meminjam printer pada pegawai di sebelahnya dan juga struktur bangunan kantor bisa dikatakan masih usang”. Fasilitas kerja yang kurang memadai ini akan memperlambat produktivitas kerja seperti turunnya suasana hati/antusias kerja pegawai.

Penelitian ini merujuk pada hasil penelitian terdahulu yang sejenis yang dilakukan oleh Lubis (2019) menyatakan bahwa kompetensi, disiplin kerja, dan lingkungan kerja berpengaruh positif dan signifikan terhadap kinerja karyawan. Hasil dari penelitian Sunarto et.al., (2020) 
menyatakan bahwa secara simultan kompetensi, disiplin kerja, dan lingkungan kerja berpengaruh terhadap kinerja karyawan dan secara parsial kompetensi, disiplin kerja, dan lingkungan kerja berpengaruh positif dan signifikan terhadap kinerja. Herry dan Saputra (2021) menyatakan bahwa kompetensi, komunikasi, kedisiplinan, lingkungan kerja secara parsial berpengaruh positif dan signifikan terhadap kinerja karyawan. Penelitian Padilah et.al., (2021) dengan hasil kepuasan kerja, motivasi kerja, lingkungan kerja, dan disiplin kerja berpengaruh dan signifikan terhadap kinerja karyawan. Adapun tujuan penelitian ini ialah untuk mengetahui pengaruh disiplin kerja, lingkungan kerja dan kompetensi terhadap kinerja karyawan Dinas Pemberdayaan Masyarakat dan Desa Kabupaten Nganjuk.

\section{KAJIAN PUSTAKA \\ Kinerja}

Menurut Kasmir (2019:182) kinerja adalah hasil kerja dan tindakan yang dicapai dengan memenuhi tugas dan tanggung jawab yang diberikan dalam jangka waktu tertentu, sedangkan menurut Afandi (2021:83-84) kinerja adalah kesediaan seseorang atau sekelompok orang untuk melakukan atau meningkatkan kegiatan sesuai dengan tanggung jawabnya dengan hasil yang diharapkan.

Ada beberapa indikator kinerja menurut Kasmir (2019:208-209) yaitu: Kualitas (Mutu) yaitu Pengukuran kinerja dapat dilakukan dengan melihat kualitas (mutu) pekerjaan yang dihasilkan oleh suatu proses tertentu. Kuantitas yaitu untuk mengukur kinerja, juga bisa dilakukan dengan cara melihat dari kuantitas (jumlah) yang dihasilkan seseorang. Waktu yaitu untuk jenis pekerjaan tertentu, ada batas waktu penyelesaian pekerjaan. Jika terjadi pelanggaran atau ketidakpatuhan terhadap tenggat waktu, dapat diasumsikan bahwa kinerjanya tidak baik dan sebaliknya. Ketepatan waktu yaitu di mana kegiatan dapat diselesaikan atau hasil produksi dapat dicapai dalam jangka waktu yang ditentukan.

\section{Disiplin Kerja}

Menurut Wahjono et.al., (2020:140) disiplin adalah kegiatan manajemen untuk menerapkan standar organisasi, sedangkan menurut Afandi (2021:11) disiplin kerja adalah suatu perintah atau peraturan yang dikeluarkan oleh pengurus suatu organisasi, agar para anggota organisasi tersebut mematuhi peraturan yang berlaku, sehingga melalui proses serangkaian perilaku yang muncul dan dibentuk yang menunjukkan nilai-nilai ketaatan, ketaatan, ketertiban dan ketertiban.

Menurut Afandi (2021:21) ada beberapa dimensi dan indikator disiplin kerja yaitu : dimensi ketaatan waktu, dengan indikator masuk kerja tepat waktu, penggunaan waktu secara efektif, tidak pernah mangkir/tidak bekerja dan dimensi tanggungjawab kerja, dengan indikator mematuhi semua peraturan organisasi atau perusahaan, target perusahaan, membuat laporan kerja harian

\section{Lingkungan Kerja}

Menurut Kasmir (2019:192) lingkungan kerja adalah suasana atau keadaan di sekitar tempat kerja, yang dapat berupa ruangan, denah, sarana dan prasarana, serta hubungan kerja dengan rekan kerja sedangkan menurut Afandi (2021:65) lingkungan kerja adalah segala sesuatu yang ada di sekitar karyawan dan dapat mempengaruhi kinerja tugas-tugas yang dibebankan kepadanya, misalnya dengan adanya air conditioner (AC), penerangan yang cukup dan sebagainya.

Ada beberapa indikator lingkungan kerja menurut Afandi (2021:71-72) yaitu: lampu penerangan tempat kerja, jendela tempat kerja, tata warna, dekorasi, bunyi musik, suhu udara kelembaban udara 


\section{Kompetensi}

Kompetensi yaitu sifat dasar perilaku yang menjelaskan motivasi, sifat pribadi, konsep diri, nilai, pengetahuan, atau keterampilan orang yang baik di tempat kerja. Menurut Wibowo (2016:271) kompetensi adalah kemampuan untuk melakukan atau melakukan suatu kegiatan dan tugas berdasarkan keterampilan dan pengetahuan yang didukung oleh sikap kerja yang diperlukan untuk kegiatan tersebut. Menurut Wibowo (2016:273) ada beberapa indikator kompetensi yaitu motif, sifat, konsep diri, pengetahuan, keterampilan.

Berdasarkan hasil uraian diatas, dalam penelitian ini diuraikan kerangka konseptual sebagai berikut:

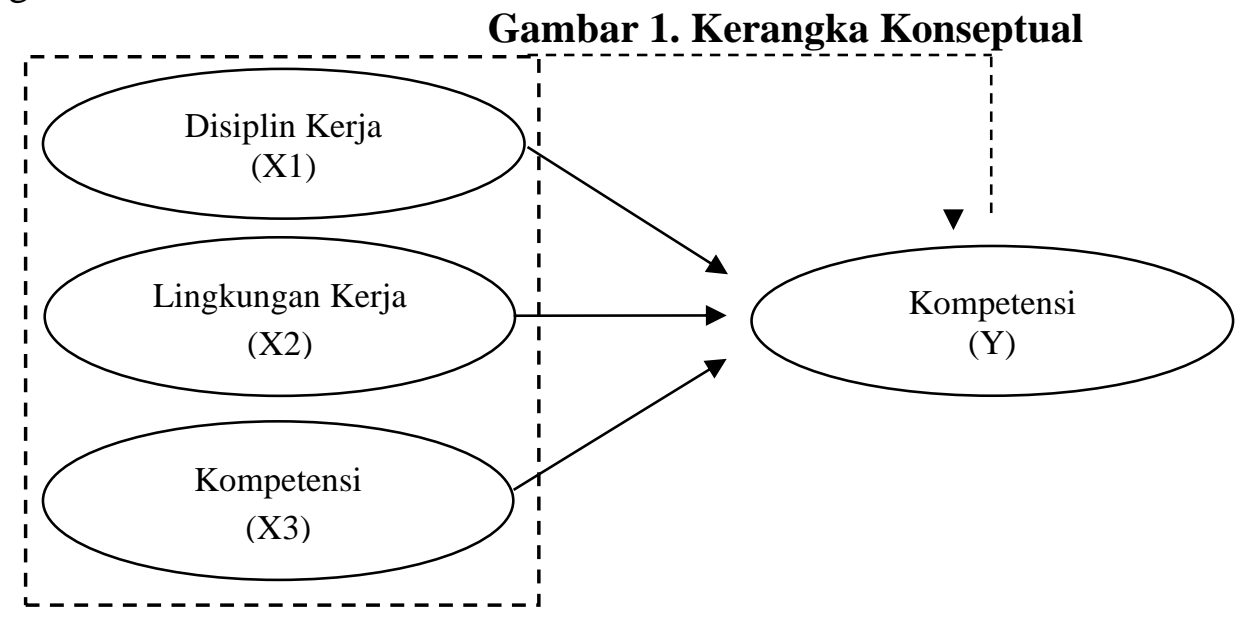

Sumber: Hasil Olahan Penulis (2021)

Berdasarkan kerangka pemikiran diatas, peneliti menyimpulkan hipotesis secara simultan dan parsial sebagai berikut:

H1: Disiplin kerja berpengaruh positif dan signifikan secara parsial terhadap kinerja pegawai Dinas Pemberdayaan Masyarakat dan Desa Kabupaten Nganjuk.

H2: Lingkungan kerja berpengaruh positif dan signifikan secara parsial terhadap kinerja pegawai Dinas Pemberdayaan Masyarakat dan Desa Kabupaten Nganjuk.

H3: Kompetensi berpengaruh positif dan signifikan secara parsial terhadap kinerja pegawai Dinas Pemberdayaan Masyarakat dan Desa Kabupaten Nganjuk.

H4: Disiplin kerja, lingkungan kerja dan kompetensi berpengaruh positif dan signifikan secara simultan terhadap kinerja pegawai Dinas Pemberdayaan Masyarakat dan Desa Kabupaten Nganjuk.

\section{METODE}

Jenis penelitian ini ialah penelitian kuantitatif, yaitu penelitian yang berguna untuk menganalisis suatu variabel independent mempengaruhi variabel dependent. Lokasi dalam penelitian ini yaitu di Dinas Pemberdayaan Masyarakat dan Desa J1. Raya Kedondong No.03, Sanggrahan, Kedondong, Kecamatan Bagor, Kabupaten Nganjuk, Jawa Timur 64461 dan waktu penelitian ini berlangsung sejak bulan Oktober 2021-Desember 2021.

Populasi dan sampel dalam penelitian ini adalah seluruh pegawai Dinas Pemberdayaan Masyarakat dan Desa Kabupaten Nganjuk yang berjumlah 42 (empat puluh dua) orang pegawai yang terdiri dari 28 Pegawai Negeri Sipil (PNS) dan 14 Tenaga Harian Lepas (THL).

Untuk memperoleh data yang diperlukan dalam penelitian ini, peneliti menggunakan beberapa Teknik pengumpulan data yaitu: interview, observasi, dan kuesioner. 1). Interview yaitu peneliti menemui kasubbag umum dan staff Dinas PMD untuk mendapatkan informasi yang lebih mendalam terkait Dinas Pemberdayaan Masyarakat dan Desa Kabupaten Nganjuk. 2). Observasi yaitu peneliti melakukan penelitian langsung di Dinas Pemberdayaan Masyarakat 
dan Desa Kabupaten Nganjuk. 3). Kuesioner yaitu peneliti membagikan Pernyataan berupa angket kepada seluruh pegawai Dinas Pemberdayaan Masyarakat dan Desa Kabupaten Nganjuk. Adapun teknis data yang digunakan oleh peneliti yang terdiri dari: uji validitas dan uji reliabilitas, uji asumsi klasik, analisis regresi linier berganda dan uji hipotesis.

\section{HASIL DAN PEMBAHASAN Deskripsi Data Responden}

Hasil perhitungan statistik menunjukkan bahwa Sebagian besar responden adalah lakilaki sebanyak 23 (55\%) orang, sedangkan responden perempuan sebanyak 19 (45\%) orang. Berdasarkan usia responden dari 42 orang, dapat diketahui jumlah responden karyawan Dinas PMD Kabupaten Nganjuk yang paling banyak adalah yang berusia $>40$ s/d 49 sebanyak 16 responden atau 38,1\%. Responden karyawan karyawan Dinas PMD Kabupaten Nganjuk yang paling sedikit adalah yang berusia $\leq 29$ sebanyak 3 responden atau 7,1\%. Selanjutnya, responden karyawan Dinas PMD Kabupaten Nganjuk yang berusia >30 s/d 39 sebanyak 14 responden atau 33,3\%. Terakhir, responden karyawan Dinas PMD Kabupaten Nganjuk yang berusia $\geq 50$ tahun sebanyak 9 responden atau $21,4 \%$.

\section{Hasil Uji Validitas dan Reliabilitas}

Tabel 1. Uji Validitas

\begin{tabular}{|c|c|c|c|c|}
\hline Variabel & Pernyataan & r-Hitung & r-Tabel & Keterangan \\
\hline \multirow[t]{10}{*}{ Disiplin Kerja } & $\mathrm{X} 1.1$ & 0,568 & 0,304 & Valid \\
\hline & $\mathrm{X} 1.2$ & 0,396 & 0,304 & Valid \\
\hline & $\mathrm{X} 1.3$ & 0,581 & 0,304 & Valid \\
\hline & $\mathrm{X} 1.4$ & 0,406 & 0,304 & Valid \\
\hline & $\mathrm{X} 1.5$ & 0,538 & 0,304 & Valid \\
\hline & $\mathrm{X} 1.6$ & 0,321 & 0,304 & Valid \\
\hline & $\mathrm{X} 1.7$ & 0,510 & 0,304 & Valid \\
\hline & $\mathrm{X} 1.8$ & 0,507 & 0,304 & Valid \\
\hline & $\mathrm{X} 1.9$ & 0,450 & 0,304 & Valid \\
\hline & $\mathrm{X} 1.10$ & 0,556 & 0,304 & Valid \\
\hline \multirow[t]{10}{*}{ Lingkungan kerja } & $\mathrm{X} 2.1$ & 0,515 & 0,304 & Valid \\
\hline & $\mathrm{X} 2.2$ & 0,378 & 0,304 & Valid \\
\hline & $\mathrm{X} 2.3$ & 0,471 & 0,304 & Valid \\
\hline & $\mathrm{X} 2.4$ & 0,751 & 0,304 & Valid \\
\hline & $\mathrm{X} 2.5$ & 0,433 & 0,304 & Valid \\
\hline & $\mathrm{X} 2.6$ & 0,531 & 0,304 & Valid \\
\hline & $\mathrm{X} 2.7$ & 0,519 & 0,304 & Valid \\
\hline & $\mathrm{X} 2.8$ & 0,478 & 0,304 & Valid \\
\hline & X2.9 & 0,495 & 0,304 & Valid \\
\hline & $\mathrm{X} 2.10$ & 0,751 & 0,304 & Valid \\
\hline \multirow[t]{10}{*}{ Kompetensi } & $\mathrm{X} 3.1$ & 0,438 & 0,304 & Valid \\
\hline & $\mathrm{X} 3.2$ & 0,483 & 0,304 & Valid \\
\hline & X3.3 & 0,529 & 0,304 & Valid \\
\hline & X3.4 & 0,549 & 0,304 & Valid \\
\hline & X3.5 & 0,606 & 0,304 & Valid \\
\hline & X3.6 & 0,591 & 0,304 & Valid \\
\hline & X3.7 & 0,567 & 0,304 & Valid \\
\hline & X3.8 & 0,668 & 0,304 & Valid \\
\hline & X3.9 & 0,509 & 0,304 & Valid \\
\hline & X3.10 & 0,460 & 0,304 & Valid \\
\hline \multirow[t]{3}{*}{ Kinerja Karyawan } & Y.1 & 0,446 & 0,304 & Valid \\
\hline & Y.2 & 0,380 & 0,304 & Valid \\
\hline & Y.3 & 0,584 & 0,304 & Valid \\
\hline
\end{tabular}




\begin{tabular}{lllll}
\hline & Y.4 & 0,527 & 0,304 & Valid \\
\cline { 2 - 5 } Y.5 & 0,414 & 0,304 & Valid \\
\cline { 2 - 5 } Y.6 & 0,399 & 0,304 & Valid \\
\cline { 2 - 5 } Y.7 & 0,445 & 0,304 & Valid \\
\hline Y.8 & 0,325 & 0,304 & Valid \\
\cline { 2 - 5 } Y.9 & 0,514 & 0,304 & Valid \\
\cline { 2 - 5 } & Y.10 & 0,699 & 0,304 & Valid \\
\hline
\end{tabular}

Sumber: data primer diolah, 2021

Berdasarkan tabel 1 menunjukkan tingkat validitas dari instrumen yang digunakan cukup bagus. Nilai $r_{\text {hitung }}$ semua item pernyataan di atas lebih dari $r_{\text {tabel }}$ yaitu 0,304. Dengan dengan demikian seluruh item pernyataan pada instrumen penelitian dinyatakan valid.

Tabel 2. Uji Reliabilitas

\begin{tabular}{lccc}
\hline \multicolumn{1}{c}{ Variabel } & Nilai Cronbach Alpha & $\begin{array}{c}\text { Kriteria } \\
\text { Nilai }\end{array}$ & Keterangan \\
\hline Disiplin kerja (X1) & 0,638 & 0,6 & Reliabel \\
\hline Lingkungan kerja (X2) & 0,722 & 0,6 & Reliabel \\
\hline Kompetensi (X3) & 0,727 & 0,6 & Reliabel \\
\hline Kinerja karyawan (Y) & 0,618 & 0,6 & Reliabel \\
\hline
\end{tabular}

Sumber: data primer yang diolah, 2021

Berdasarkan tabel 2 menunjukkan hasil uji reliabilitas di atas, diketahui bahwa variabel displin kerja, lingkungan kerja, kompetensi dan kinerja karyawan dinyatakan reliabel, karena mempunyai nilai lebih besar dari 0,6 .

\section{Uji Asumsi Klasik}

\section{Uji Normalitas}

\section{Gambar 2. Uji Normalitas}
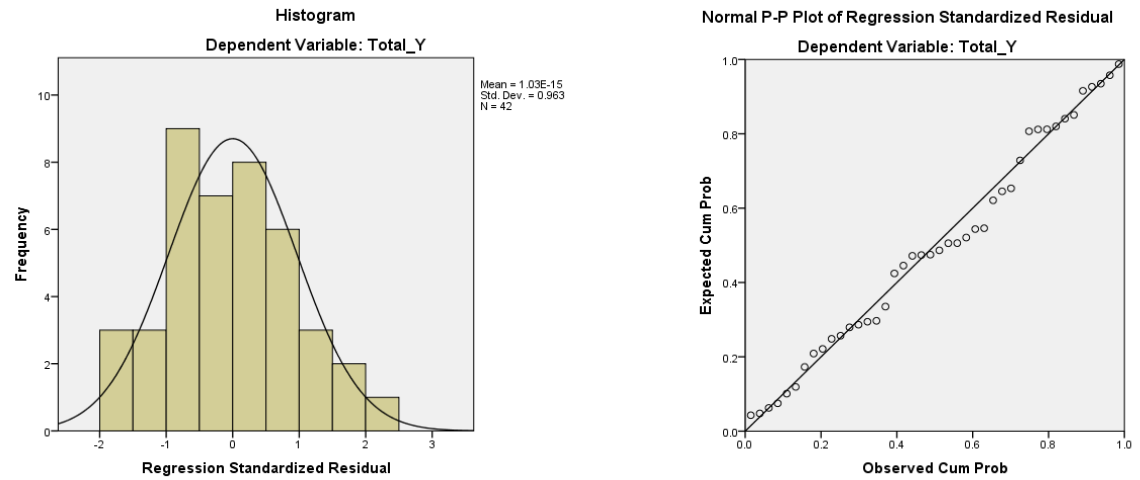

Sumber: data primer diolah, 2021

Berdasarkan gambar 2 hasil uji normalitas dapat diketahui bahwa data yang dianalisis telah berdistribusi secara normal. Hasil gambar histogram menunjukkan data variabel berbentuk seperti lonceng. Sedangkan pada hasil gambar normal probability plot menunjukkan titik-titik atau data menyebar di sekitar garis diagonal dan mengikuti arah garis diagonal, sehingga model regresi ini memenuhi asumsi normalitas. 
Journal of Law, Administration, and Social Science

Volume 1 No. 2, Desember 2021

\section{Uji Multikolinieritas}

Tabel 3. Uji Multikolinieritas

Coefficients $^{\mathrm{a}}$

\begin{tabular}{|c|c|c|c|}
\hline \multirow[b]{2}{*}{ Model } & & \multicolumn{2}{|c|}{ Collinearity Statistics } \\
\hline & & Tolerance & VIF \\
\hline \multirow[t]{4}{*}{1} & (Constant) & & \\
\hline & Disiplin & ,313 & 3,199 \\
\hline & Lingkungan &, 538 & 1,857 \\
\hline & Kompetensi & ,347 & 2,884 \\
\hline
\end{tabular}

a. Dependent Variabel : Kinerja karyawan

Sumber: Data primer diolah, 2021

Berdasarkan tabel 3 diketahui nilai VIF masing-masing variabel yaitu variabel Disiplin kerja sebesar 3,199, variabel Lingkungan kerja sebesar 1,857 dan variabel Kompetensi sebesar 2,884. Terlihat dari tiga nilai variabel tersebut memiliki nilai VIF lebih kecil dari 10 dan dengan nilai tolerance lebih besar dari 0,10 , dengan demikian dalam model regresi ini tidak terjadi multikolinieritas antar variabel independen.

Uji Heteroskedastisitas

\section{Gambar 3. Uji Heteroskedastisitas}

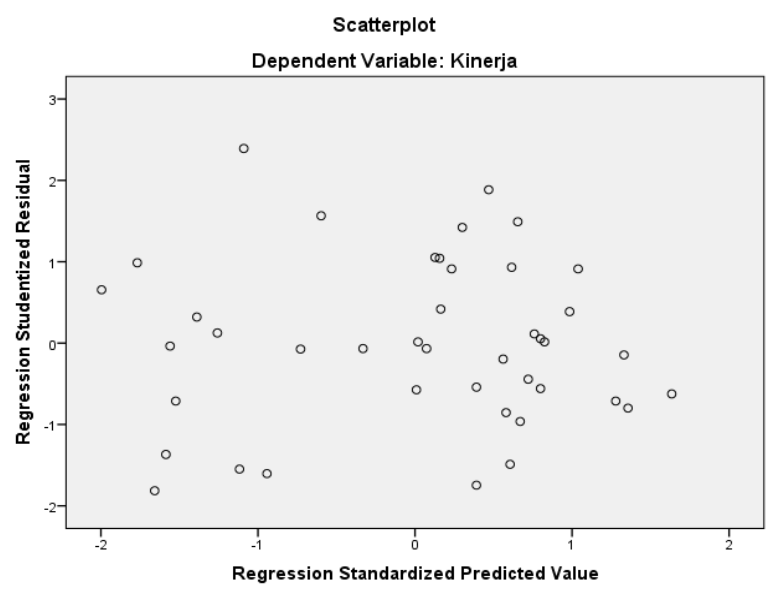

Sumber: Data primer diolah, 2021

Pada gambar 3 gafik scatterplots terlihat bahwa titik-titik menyebar secara acak dan tidak menunjukkan pola tertentu, tersebar baik di atas maupun di bawah 0 pada sumbu Y. Sehingga diketahui model regresi tidak terjadi heteroskedastisitas.

\section{Uji Regresi Linier Berganda}

Tabel 4. Analisis Regresi Linier Berganda Coefficient $^{\text {a }}$

\begin{tabular}{llrrrrr}
\hline & \multicolumn{7}{c}{$\begin{array}{c}\text { Unstandardized } \\
\text { Coefficients }\end{array}$} & \multicolumn{2}{c}{$\begin{array}{c}\text { Standardized } \\
\text { Coefficients }\end{array}$} \\
Model & \multicolumn{1}{c}{ B } & Std. Error & \multicolumn{1}{c}{ Beta } & \multicolumn{1}{c}{ t } & \multicolumn{1}{c}{ Sig. } \\
\hline 1 & (Constant) & 6,761 & 3,970 & & 1,703 &, 097 \\
& Disiplin &, 295 &, 152 &, 307 & 1,935 &, 060 \\
& Lingkungan &, 359 &, 107 &, 405 & 3,345 &, 002 \\
& Kompetensi &, 198 &, 132 &, 227 & 1,504 &, 141 \\
\hline
\end{tabular}

a. Dependen variabel: Kinerja karyawan

Sumber: Data primer diolah, 2021

Berdasarkan tabel 4.4, diperoleh persamaan regresi linier berganda sebagai berikut: 


$$
Y=6,761+0,295 X 1+0,359 X 2+0,198 X 3+e
$$

Persamaan regresi di atas mempunyai angka makna sebagai berikut:

Konstanta $=6,761$, nilai tersebut menunjukkan bahwa jika variabel Disiplin kerja $\left(\mathrm{X}_{1}\right)$, Lingkungan kerja $\left(\mathrm{X}_{2}\right)$ dan Kompetensi (X3) bernilai 0, maka nilai kinerja karyawan (Y) adalah 6,761. Koefisien $X_{1}=0,295$ artinya jika terjadi peningkatan variabel $X_{1}$ (Disiplin kerja) sebesar 1 satuan, maka Y (kinerja karyawan) akan naik sebesar 0,295 satuan. Koefisien $\mathrm{X}_{2}=0,359$ artinya jika terjadi peningkatan variabel $\mathrm{X}_{2}$ (Lingkungan kerja) sebesar 1 satuan, maka $\mathrm{Y}$ (kinerja karyawan) akan naik sebesar 0,359. Koefisien $X_{3}=0,198$ artinya jika terjadi peningkatan variabel $\mathrm{X}_{3}$ (Kompetensi) sebesar 1 satuan, maka $\mathrm{Y}$ (kinerja karyawan) akan naik sebesar 0,198 satuan. Variabel yang berpengaruh paling dominan adalah variabel lingkungan kerja yang memiliki nilai koefisien B (beta) paling besar yaitu sebesar 0,359

\section{Pengujian Hipotesis}

\section{Uji-t (Parsial)}

Tabel 5. Uji-t (Parsial)

Coefficients $^{\text {a }}$

\begin{tabular}{|c|c|c|c|c|}
\hline \multirow{2}{*}{\multicolumn{2}{|c|}{ Model }} & $\begin{array}{c}\text { Standardized } \\
\text { coefficients }\end{array}$ & \multirow[b]{2}{*}{$\mathrm{t}$} & \multirow[b]{2}{*}{ Sig. } \\
\hline & & \multirow[t]{2}{*}{ Beta } & & \\
\hline 1 & (Constant) & & 1,703 & ,097 \\
\hline & Disiplin & ,307 & 1,935 & ,060 \\
\hline & Lingkungan & ,405 & 3,345 &, 002 \\
\hline & Kompetensi & ,227 & 1,504 & , 141 \\
\hline
\end{tabular}

a. Dependen variabel: Kinerja karyawan

Sumber: Data primer diolah, 2021

Tabel 5 menunjukkan hasil pengujian uji-t yang dijelaskan sebagai berikut:

Berdasarkan hasil perhitungan pada tabel 5 diperoleh nilai $t_{\text {hitung }}=1,935<t_{\text {tabel }}$ $(0,025 ; 38)=2,024$ atau nilai sig $=0,060>0,05$, maka H0 diterima dan Ha ditolak. Artinya, variabel disiplin kerja secara parsial berpengaruh positif namun tidak signifikan terhadap kinerja karyawan.

Berdasarkan hasil perhitungan pada tabel 5 diperoleh nilai $t_{\text {hitung }}=3,345>t_{\text {tabel }}$ $(0,025 ; 38)=2,024$ atau nilai sig $=0,002<0,05$, maka H0 ditolak dan Ha diterima. Artinya, variabel lingkungan kerja secara parsial berpengaruh positif dan signifikan terhadap kinerja karyawan.

Berdasarkan hasil perhitungan pada tabel 5 diperoleh nilai $t_{\text {hitung }}=1,504<\mathrm{t}_{\text {tabel }}$ $(0,025 ; 38)=2,024$ atau nilai sig $=0,141>0,05$, maka H0 diterima dan Ha ditolak. Artinya, variabel kompetensi secara parsial berpengaruh positif namun tidak signifikan terhadap kinerja karyawan.

\section{Uji-F(Simultan)}

Tabel 6. Uji-F (Simultan) ANOVA $^{a}$

\begin{tabular}{llrlr}
\hline Model & & df & F & Sig. \\
\hline 1 & Regression & 3 & 29,593 &, $000^{\mathrm{b}}$ \\
& Residual & 38 & & \\
& Total & 41 & & \\
\hline
\end{tabular}

a. Dependent variable: Kinerja karyawan

b. Predictors: (Constant), Kompetensi,Lingkungan,Disiplin Sumber: Data primer diolah, 2021 
Berdasarkan hasil uji-F pada tabel 6 diperoleh nilai $\mathrm{F}_{\text {hitung }}=29,593>\mathrm{F}_{\text {tabel }}(3,38)=2,83$ atau nilai sig sebesar 0,000 yang mana nilai tersebut lebih kecil dari 0,05, maka hipotesis $\mathrm{H} 0$ ditolak dan Ha diterima. Artinya, variabel disiplin kerja, lingkungan kerja, dan kompetensi secara simultan berpengaruh positif dan signifikan terhadap variabel kinerja karyawan.

\section{Pengaruh Disiplin Kerja Terhadap Kinerja Karyawan}

H1: Yang berbunyi disiplin kerja berpengaruh positif dan signifikan secara parsial terhadap kinerja pegawai Dinas Pemberdayaan Masyarakat dan desa Kabupaten Nganjuk, "ditolak". Ketika diterapkannya disiplin kerja yang tinggi oleh pimpinan kepada karyawan Dinas PMD, maka tidak akan mempengaruhi kinerja karyawan Dinas PMD Kabupaten Nganjuk. Karena sebagian besar karyawan Dinas PMD adalah seorang Pegawai Negeri Sipil (PNS), yang memberi kompensasi karyawan yang berstatus Pegawai Negeri Sipil bukanlah kantor itu sendiri melainkan diberi gaji oleh negara. Sehingga jika karyawan izin sakit maupun tidak masuk bekerja, mereka akan tetap diberi gaji oleh negara.Hasil dari penelitian ini tidak sesuai dengan penelitian terdahulu yang dilakukan oleh (Handayani et.al., 2019), (Sunarto et.al., 2020), (Padilah et.al., 2021), (Herry dan Saputra, 2021), yang mengemukakan disiplin kerja berpengaruh positif dan signifikan terhadap kinerja karyawan.

\section{Pengaruh Lingkungan Kerja Terhadap Kinerja Karyawan}

H2: Yang berbunyi lingkungan kerja berpengaruh positif dan signifikan secara parsial terhadap kinerja pegawai Dinas Pemberdayaan Masyarakat dan desa Kabupaten Nganjuk, "diterima". Berarti bahwa, lingkungan kerja yang kondusif akan memberikan rasa aman dan memungkinkan karyawan untuk dapat bekerja secara optimal (Afandi, 2021). Dalam Dinas PMD Kabupaten Nganjuk terdapat berbagai fasilitas yang kurang memadai seperti komputer yang digunakan untuk bekerja sehari-hari sudah waktunya untuk upgrade dan juga tata ruang/bangunan kantor waktunya untuk tahap renovasi, dalam permasalahan ini semua dibenahi dan fasilitas kantor sudah cukup memadai maka akan meningkatkan kinerja karyawan Dinas PMD Kabupaten Nganjuk. Hasil penelitian ini sesuai dengan penelitian terdahulu yang dilakukan oleh (Handayani et.al., 2019), (Adha et.al., 2019), (Sunarto et.al., 2020), (Padilah et.al., 2021), (Herry dan Saputra, 2021) yang mengemukakan lingkungan kerja berpengaruh positif dan signifikan terhadap kinerja karyawan.

\section{Pengaruh Kompetensi Terhadap Kinerja Karyawan}

H3: Yang berbunyi kompetensi berpengaruh positif dan signifikan secara parsial terhadap kinerja pegawai Dinas Pemberdayaan Masyarakat dan desa Kabupaten Nganjuk, "ditolak". Berarti bahwa, karyawan yang memiliki pedidikan formal dan informal yang tinggi tidak akan mempengaruhi kinerja pegawai Dinas Pemberdayaan Masyarakat dan Desa Kabupaten Nganjuk. Dalam hal ini kompetensi PNS berkaitan dengan kemampuan, keterampilan, maupun perilaku yang dibutuhkan untuk melaksanakan tugas pokok, fungsi kewenangan dan tanggungjawab yang telah diamanatkan kepadanya namun, kompetensi ini hanya untuk pendamping formalitas saja untuk persyaratan menjadi PNS dan juga dengan tingkat pendidikan yang tinggi, akan dapat menaikkan suatu jabatan/gaji saja. Sehingga kompetensi tidak berpengaruh begitu signifikan terhadap kinerja karyawan. Hasil dari penelitian ini tidak sesuai dengan penelitian terdahulu yang dilakukan oleh (Sunarto et.al., 2020), (Herry dan Saputra, 2021), yang mengemukakan kompetensi berpengaruh positif dan signifikan terhadap kinerja karyawan.

\section{Pengaruh Disiplin Kerja, Lingkungan Kerja dan Kompetensi Terhadap Kinerja Karyawan}

H4: Yang berbunyi disiplin kerja, lingkungan kerja, kompetensi berpengaruh positif dan signifikan secara simultan terhadap kinerja pegawai Dinas Pemberdayaan Masyarakat dan Desa Kabupaten Nganjuk, "diterima". Berarti bahwa disiplin, lingkungan kerja dan kompetensi sama-sama memiliki pengaruh positif terhadap kinerja karyawan Dinas Pemberdayaan 
Masyarakat dan Desa Kabupaten Nganjuk maka akan meningkatkan kualitas kinerja karyawan Dinas Pemberdayaan Masyarakat dan Desa Kabupaten Nganjuk. Hasil penelitian ini sesuai dengan penelitian terdahulu yang dilakukan oleh, (Sunarto et.al., 2020), (Lubis, 2019) yang mengemukakan disiplin kerja,lingkungan kerja dan kompetensi berpengaruh positif dan signifikan secara simultan terhadap kinerja karyawan.

\section{PENUTUP}

\section{Simpulan}

Disiplin kerja berpengaruh positif namun tidak signifikan secara parsial terhadap kinerja karyawan Dinas Pemberdayaan Masyarakat dan Desa Kabupaten Nganjuk dengan hasil perhitungan nilai $t_{\text {hitung }}=1,935<\mathrm{t}_{\text {tabel }}(0,025 ; 38)=2,024$ atau nilai sig $=0,060>0,05$, maka hipotesis $\mathrm{H0}$ diterima dan Ha ditolak artinya semakin ditingkatkannya disiplin kerja tidak akan mempengaruhi kinerja karyawan Dinas Pemberdayaan Masyarakat dan Desa Kabupaten Nganjuk.

Lingkungan kerja mempunyai pengaruh positif dan signifikan secara parsial terhadap kinerja karyawan Dinas Pemberdayaan Masyarakat dan Desa Kabupaten Nganjuk dengan hasil perhitungan nilai $t_{\text {hitung }}=3,345>\mathrm{t}_{\text {tabel }}(0,025 ; 38)=2,024$ atau nilai sig $=0,002<0,05$, maka hipotesis $\mathrm{HO}$ ditolak dan Ha diterima artinya semakin ditingkatkannya lingkungan kerja seperti fasilitas kerja yang memadai, tata ruangan yang memadai, hubungan antar karyawan baik, maka akan meningkatkan kinerja karyawan Dinas Pemberdayaan Masyarakat dan Desa Kabupaten Nganjuk.

Kompetensi berpengaruh positif namun tidak signifikan secara parsial terhadap kinerja karyawan Dinas Pemberdayaan Masyarakat dan Desa Kabupaten Nganjuk dengan hasil perhitungan nilai $\mathrm{t}_{\text {hitung }}=1,504<\mathrm{t}_{\text {tabel }}(0,025 ; 38)=2,024$ atau nilai sig $=0,141>0,05$, maka hipotesis $\mathrm{HO}$ diterima dan Ha ditolak artinya semakin tinggi tingkat kompetensi karyawan tidak akan mempengaruhi kinerja karyawan Dinas Pemberdayaan Masyarakat dan Desa Kabupaten Nganjuk.

Disiplin kerja, lingkungan kerja dan kompetensi mempunyai pengaruh positif dan signifikan secara simultan terhadap kinerja karyawan Dinas Pemberdayaan Masyarakat dan Desa Kabupaten Nganjuk dengan hasil perhitungan nilai $F_{\text {hitung }}=29,593>F_{\text {tabel }}(3,38)=2,83$ atau nilai sig sebesar 0,000 yang mana nilai tersebut lebih kecil dari 0,05, maka hipotesis $\mathrm{H} 0$ ditolak dan $\mathrm{Ha}$ diterima artinya bila disiplin kerja, lingkungan kerja dan kompetensi ditingkatkan di dalam Dinas Pemberdayaan Masyarakat dan Desa Kabupaten Nganjuk. maka akan mempengaruhi kinerja karyawan Dinas Pemberdayaan Masyarakat dan Desa Kabupaten Nganjuk.

\section{Saran}

Bagi Dinas Pemberdayaan Masyarakat dan Desa Kabupaten Nganjuk, disiplin kerja dalam organisasi harus dipertahankan karena disiplin kerja yang baik akan menumbuhkan pribadi yang baik juga akan meingkatkan reputasi sebuah organisasi dan lingkungan kerja dalam Dinas PMD Kabupaten Nganjuk perlu adanya peremajaan seperti struktur bangunan, fasilitas mobil kantor, komputer yang sudah usang perlu untuk peremajaan maupun penganggaran ulang, karena fasilitas kerja tersebut akan mempengaruhi produktivitas kinerja karyawan dalam pekerjaannya sehari-hari.

Bagi Peneliti Selanjutnya, hasil penelitian ini dapat dijadikan referensi maupun dijadikan penelitian lanjutan khususnya di bidang kajian yang sama. Penelitian selanjutnya diharapkan bisa memperluas variabel penelitian sehingga dapat menghasilkan penelitian yang baik. 


\section{DAFTAR PUSTAKA}

Adha, R. N., Qomariah, N., \& Hafidzi, A. H. (2019). Pengaruh Motivasi Kerja , Lingkungan Kerja , Budaya Kerja Terhadap Kinerja Karyawan Dinas Sosial Kabupaten Jember. Jurnal Penelitian Ipteks, 4(1), 47-62.

Afandi, P. (2021). Manajemen Sumber Daya Manusia;Teori,Konsep dan Indikator (edisi ke2). ZANAFA PUBLISHING.

Handayani, E., Meryati, \& Laela, S. (2019). Analisis disiplin dan lingkungan kerja serta pengaruhnya terhadap kinerja pegawai pada asisten deputi sdm pariwisata dan hubungan antar lembaga kementerian pariwisata RI. Jurnal Manajemen Kewirausahaan, 16(02), 157-168. https://doi.org/http://dx.doi.org/10.33370/jmk.v16i2.353

Herry, K., \& Saputra, N. A. (2021). Kompetensi, Komunikasi, Kedisiplinan, Dan Lingkungan Kerja Terhadap Kinerja Karyawan. Jurnal Manajemen, 17(1), 13-26.

Kasmir. (2019). Manajemen Sumber Daya Manusia (Teori dan Praktik) (Edisi ke-5). PT RAJA GRAFINDO PERSADA.

Lubis, A. khairani. (2019). Pengaruh Kompetensi, Disiplin dan Lingkungan Kerja Terhadap Kinerja Pegawai Diskominfo Kota Medan.

Padilah, Serang, S., \& Amir. (2021). PARADOKS : JURNAL ILMU EKONOMI Volume 4 . No . 2 ( 2021 ); April dan Disiplin Kerja Terhadap Kinerja Karyawan Pada PT . Zam-. Jurnal Ilmu Ekonomi, 4(2).

Sunarto, A., Qurbani, D., \& Virby, S. (2020). Pengaruh Kompetensi , Disiplin Kerja Dan Lingkungan Kerja Terhadap Kinerja Pada PT Anugrah Bersama Sejahtera Depok. Jurnal Ilmiah Manajemen FORKAMMA, 4(1), 1-13.

Wahjono, S. imam, Marina, A., Wardhana, A., \& Darmawan, A. (2020). Pengantar Manajemen (Edisi ke-2). PT RAJA GRAFINDO PERSADA.

Wibowo. (2016). Manajemen Kinerja (Edisi ke-1). PT RAJA GRAFINDO PERSADA. 